\title{
New tools for self-organized pattern formation
}

Kaj Bernhardt ${ }^{1}$, Nikhilesh Singh Chand*1, Elizabeth Carter ${ }^{1}$, Jisun Lee $^{2}$, Yang $\mathrm{Xu}^{2}$, Xueni Zhu ${ }^{2}$, Duncan Rowe ${ }^{1}$, JW Ajioka1 ${ }^{1}$, JM Goncalves ${ }^{2}$, J Haseloff ${ }^{1}$ and G Micklem ${ }^{1}$

\author{
Address: ${ }^{1}$ School of Biological Sciences, University of Cambridge, Cambridge, UK and ${ }^{2}$ Department of Engineering, University of Cambridge, \\ Cambridge, UK \\ Email: Nikhilesh Singh Chand* - nsc28@cam.ac.uk \\ * Corresponding author
}

from BioSysBio 2007: Systems Biology, Bioinformatics and Synthetic Biology

Manchester, UK. II-13 January 2007

Published: 8 May 2007

BMC Systems Biology 2007, I(Suppl I):SI0 doi:I0.II86/1752-0509-I-SI-SI0

This abstract is available from: http://www.biomedcentral.com/I752-0509/I?issue=SI

(c) 2007 Bernhardt et al; licensee BioMed Central Ltd.

\section{Introduction}

Multicellular organisms undergo self-organisation during development. Our aim was to engineer self-organised pattern formation in free-swimming bacteria cells by providing an artificial system for bi-directional communication. E. coli cells would be equipped with genes derived from independent quorum sensing systems from $P$. aeruginosa and $V$. fischeri. These systems enable communication between cell populations and can enable regulated switching between competing cell fates. The negotiation of cell fates within bacterial populations can be visualized precisely by the expression of different fluorescent proteins.

\section{Experiments conducted and results obtained}

Using Escherichia coli as a model system we have observed how differential cell motility can, in itself, lead to pattern formation. Adapting the experiments of Weiss et al. [1], we have studied the interactions between cell populations in swimming agar with genetically engineered sender and receiver cells. The sender cells express one of two acylhomoserine lactone (AHL) synthases whereas the receiver cells are capable of responding to the generated AHL signal. Instead of using a differential response to AHL concentrations we employed cell motility as a way to define zones of response (see Figure 1 for an example). In particular we equipped highly motile strains such as $E$. coli MC1000 with AHL-mediated autoinducing systems based on Vibrio fischeri luxI/luxR [2] and Pseudomonas aeruginosa lasI/lasR [3] cassettes. We had these auto-inducing cassettes synthesized and tested them as depicted. To obtain an enhanced response the coding sequences were codon optimized. (See Figure 2).

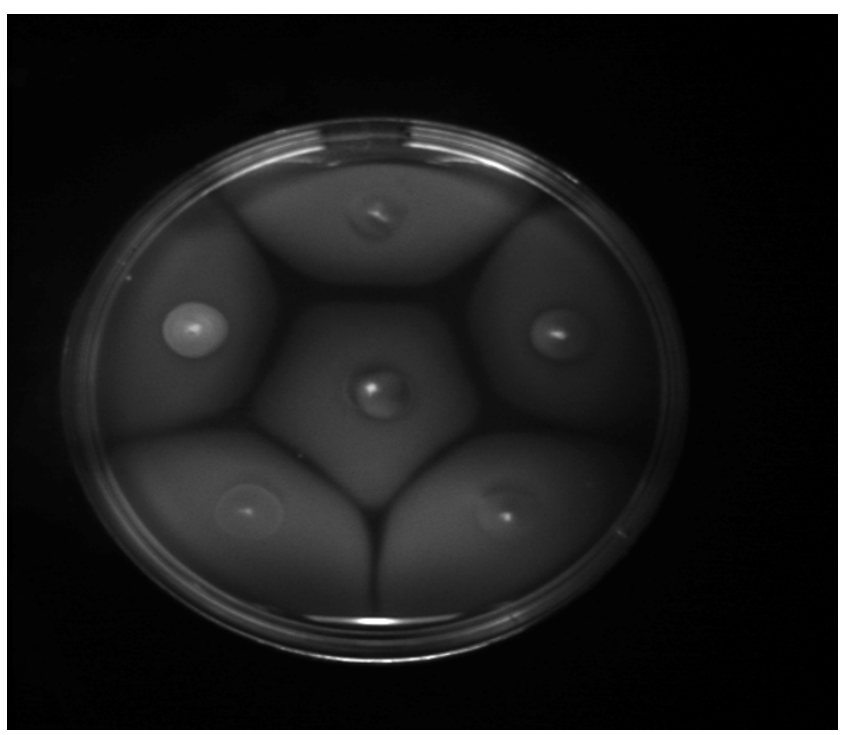

Figure I

Zones of responses defined by cell motility 


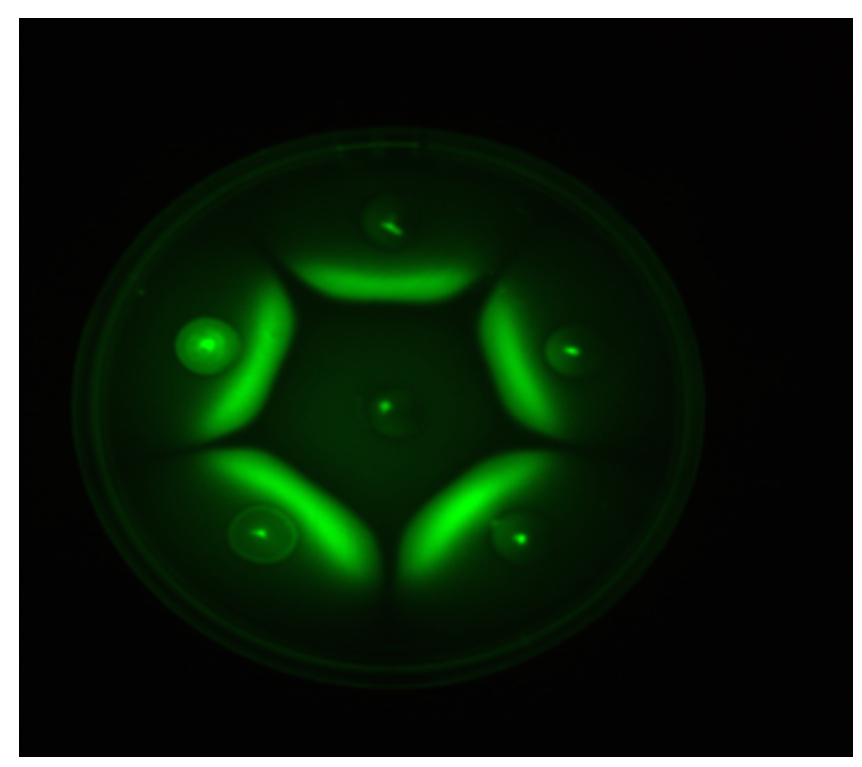

Figure 2

An enhanced response by codon optimization of the coding sequences

\section{References}

I. Basu S, et al.: A synthetic multicellular system for programmed pattern formation. Nature 2005, 434(7037): $1130-1134$.

2. Dunlap PV: Quorum regulation of luminescence in Vibrio fischeri. J Mol Microbiol Biotechnol 1999, I(I):5-I2.

3. Venturi V: Regulation of quorum sensing in Pseudomonas. FEMS Microbiol Rev 2006, 30(2):274-29I.
Publish with Biomed Central and every scientist can read your work free of charge

"BioMed Central will be the most significant development for disseminating the results of biomedical research in our lifetime. "

Sir Paul Nurse, Cancer Research UK

Your research papers will be:

- available free of charge to the entire biomedical community

- peer reviewed and published immediately upon acceptance

- cited in PubMed and archived on PubMed Central

- yours - you keep the copyright
BioMedcentral 